\title{
Preparation of Financial Policy to Increase Timing of Inpatient Billing Information of Hospital " $\mathrm{X}$ "
}

\author{
Abdi Agus Youandi", Kurnia Widyaningrum, Navis Yuliansyah \\ *Correspondent Author: abdiyouandi@yahoo.com \\ *Gatoel Mojokerto Hospital, East Java, Indonesia
}

\begin{tabular}{l}
\hline I N D E X I N G \\
\hline Keywords: \\
Workflow; \\
SOP; \\
Biling Information.
\end{tabular}

\begin{abstract}
A B S T R A C T
One of the main problems encountered in hospital $\mathrm{X}$ is the timing of inpatient billing information that has not been $\leq 2$ hours. The focus of the study was to begin when the DPJP said the patient was allowed to go home until the patient received inpatient billing information. This study aims to explore the root of the problem has not reached the standard speed of inpatient billing information. Method: This research method is qualitative research. The study was conducted at hospital X from September to October 2017. Data were collected using literature study method, document review, unit observation, in-depth interview, focus group discussion (FGD). Result: Delay of billing information due to slow recording and recording differences. Differences in recording arise due to duplicate work of nurses who have other activities. Duties nurses not only provide patient care but have the administrative task. Conclusion: The speed of inpatient billing information information has not been standardized $\leq 2$ hours due to duplicate of work of nurse having other activity. The solution to the problem is the need for revised policies and SOPs that regulate the duties, authority and responsibilities of each staff in more detail.
\end{abstract}

Kata Kunci:

Alur Kerja;

SOP;

Salah satu masalah utama yang ditemui di hospital X adalah kecepatan waktu pemberian informasi tagihan pasien rawat inap yang belum sesuai standar $\leq 2 \mathrm{jam}$. Fokus penelitian adalah dimulai ketika DPJP menyatakan pasien diperbolehkan pulang sampai pasien menerima informasi tagihan rawat inap. Penelitian ini bertujuan mengekplorasi akar masalah belum tercapainya standar kecepatan pemberian informasi tagihan rawat inap. Metode: Metode penelitian ini adalah penelitian kualitatif. Penelitian dilakukan di hospital X sejak September sampai Oktober 2017. Data dikumpulkan dengan menggunakan metode studi literatur, telaah dokumen, observasi unit, wawancara mendalam, focus group discussion (FGD). Hasil penelitian: Keterlambatan pemberian informasi tagihan disebabkan pencatatan yang lambat dan timbulnya perbedaan pencatatan. Perbedaan pencatatan timbul akibat rangkap pekerjaan perawat yang memiliki aktivitas lain. Tugas perawat tidak hanya memberikan asuhan pasien tetapi mempunyai tugas. Kesimpulan: Kecepatan pemberian informasi tagihan rawat inap belum sesuai standar $\leq 2$ jam karena adanya rangkap pekerjaan perawat yang memiliki aktifitas lain. Solusi masalah adalah perlu dilakukannya revisi kebijakan dan SOP yang mengatur tugas, wewenang serta tanggungjawab setiap staf secara lebih detail.

(C) 2018 JMMR. All rights reserved.

Article history: Received 2018-Apr-10 ; Revised 2018-Apr-11; Accepted 2018-May-04

\section{INTRODUCTION}

Hospital $\mathrm{X}$ is a hospital type $\mathrm{D}$, having the capacity of 109 beds with its total land area of $4.764,20 \mathrm{M}^{2}$ and physical buildings about 5.304,16 $\mathrm{M}^{2}$. Hospital $\mathrm{X}$ has services such as emergency room, outpatient clinic, operating room, ICU, outpatient pharmacy and inpatient clinic, radiology division, laboratory, nutritional division, laundry and installation of facility maintenance and medical record division.Minimal service standard (SPM) is made and used as a benchmark of hospital management to assess its service quality. Measurement of quality
Indicator of SPM is performed by all service units, compiled and analyzed by hospital's Quality Assurance Committee. Feedback of quality analysis is then delivered to all units through forum of regular meeting of directors, monthly and annual report. Continuous monitoring and evaluation are conducted as an effort to increase quality and patient safety.

A preliminary study was done on August 2017 by doing literature study both online and printed versions, documentary analysis, interview, observation. There were 37 problems found and brainstorming was done together with directors and narrowed into 3 problems owned by 
Hospital X. On September 2017, focus group discussion ( $F G D$ ) was done, attended by directors, heads of division, and heads of units, hospital committee representatives. One of the main problems of FGD findings is regarding timing of providing information regarding inpatient bill which is 3.4 hours. The timing of providing inpatient bill information is the waiting time for the patient until he is officially allowed to go home by the doctor in charge of the patient's medical treatment until the patient or his family gets the confirmation regarding the bill information. The time standard determined is $\leq 2$ hours ${ }^{1}$.

The presentation of information of inpatient bill in hospital $\mathrm{X}$ has been done through manual recording activity and has used billing system informationof hospital(SIRS) since 2006. SIRS was made and developed by the third party, appointed by X hospital's management. SIRS was made for patient's enrollment service and billing systemto support service provision to patients and is periodically developed to develop SIRS in accordance with $\mathrm{x}$ hospital services.SIRS becomes the integrated application for all service units.

Inpatient billing systemis a part of management information system application which serves financing of inpatient health services in hospitals ${ }^{2}$. The process of finishing administration of inpatient is a complex process, involving combined hospital service unit performance, doctors in charge of services (DPJP), nursing division, pharmacy division, patient's nutritional and dietary division, surgical division, laboratory division, and radiology division and administrative unit/inpatient cashier. If one of the parts cannot accomplish its responsibility on time, it will affect the overall speed/rate of accomplishing the responsibilites ${ }^{3}$. When patient is allowed to go home by DPJP, he will not immediately receive the information of his inpatient bill.He and his family should wait for all service transaction recordings collected, processed and then entry billing will be done which is then informed regarding how much it costs regarding inpatient bill. In other word, the speed/rate of providing inpatient bill information is the patient's waiting time to get the information regarding the bill information.

Waiting time is a vital satisfatory aspect. Waiting time and comfort are motivation, affecting customers to choose services ${ }^{4}$. The patient's experience when waiting for services can affect his perception regarding service quality. Patient coming to hospital to get medical treatments without waiting too long(5). Patient's complaints frequently occur due to insatisfactory services, high cost of medical treatment, lack of facilities.The inpatients having a tendency to see the overall aspects of hospital services due to the lengthy interaction between patient and hospital $\left({ }^{6}\right)$ Jamilatus's study in Universitas MuhammadiyahHospital Malang showed that $20 \%$ of the patients feel unsatisfied with hospital services. It was known that patient's waiting time is between 3 and 4 hours until he is allowed to go homeby DPJP ${ }^{7}$. Administrative completion of inpatients is very vital because besides patient's recovery, the patient's hospital discharge is also vital due to a quick process. In other word, every patient needs quick services, treatments and recovery as well as quick hospital discharge when the patient's health condition is getting improved. This becomes a challenge for hospital management as well as the staff to fulfill or even is able to exceed the expectation of the hospital customers.

This research aims to explore the root problems regarding unmet minimal service standard(SPM) of providing inpatient bill information in hospital X. Research focus starts when DPJP declares that the patient is allowed to go home until the patient receive the informationregarding inpatient bill. This research contributes to increase the quality of services of the hospital not only from its medical services but also from its administrative services for patients and families. A hospital capable of providing quick and easy inpatient administrative completion will be one of the appeals for people to get medical treatments.

\section{RESEARCH METHOD}

Method used in this research was qualitative descriptive. Research was conducted in X hospital from September to October 2017. Data was collected by using literature study method, documentary analysis, observation, in depth interview, focus group discussion (FGD).In depth interview was done to directors, heads of division, head of units, committee staff and verification staff. Interview was conducted to some informants in hospital $\mathrm{X}$ to get much information regarding hospital regulations, its implementations, monitoring and evaluation of providing information regarding inpatient bill information. The chosen informants were based on the information abundance thatis owned, related to the process.

Observation and in depth intervieware two techniques of primary collecting data in qualitative research as it has high accuracy and is able to gain verbal and non verbal data $^{8}$. All information gained is not only verbal data delivered by informants. It also allows the researcher to 
observe the informant's gesture and its environmental situation.

Problem identification was done by observing all processes to develop alternative solutions to increase the speed of inpatient bill information. Determining root problems used brainstormingmethod using fishbone diagram and 5 why. 5 why technique is a simple question and answer technique to investigate causal relationship that triggers a problem. A question technique of Why comprises 5 times, why a problem occurs in determining the root of the problem ${ }^{9}$. Alternative solution was developed by doing CARL method filtering(capability, accessibility, readiness and leverage), using score1-9. The alternative solution having the highest score will be a chosen solution priority to resolve the root problem.

\section{RESULT AND DISCUSSIONS}

Hospital information system(SIRS) can be characterized by its information functions and types of services offered. To support patient's medical services and its administration, SIRS should support the availability of information regarding patients, proper ways, relevance, renewal, accessible to right person having different location and uniformity of formats ${ }^{10}$. The complexity of hospital services produces a complex hospital information so that it requires reliable hospital information system so that people can rely on its usefulness.

The application of hospital information system plays a role in its service administrative functions including electronic registration function, billing system and welfare state claim system(10). Recording system of patient registration can be done manually or by utilizing computerized system orthe combination of both. Hospital X makes both manual and computerized daily transaction recordings through SIRS that the hospital already owns. Manual recording activity is performed by staff in a double form and SIRS entry was done based on its manual recording. Service data transcation is collected, saved, processed and documented to produce billing information that hospital and patient/family need.(10).

The development of administration system is suited with types and forms of services provided by the hospital as well as the provision of human resources that a hospital has as to gain the information of comprehensive and intergrated patient's medical treatment cost. Some factors affecting the implementation of SIRS are the provision of infrastructure, organization, management support and financing, national policy and the availability of human resources ${ }^{10}$.

Observational finding indicated that each unit of hospital services has been connected and intergrated in SIRS.Every type of services/medical procedures can be recorded from SIRS computer that has been available in each unit. From organizational aspect, hospital management does not in fact appoint a specific unit which performs improvement and maintanenace of SIRS.Maintenance and and repair of SIRS hardware are performed by the third party based on the proposed used needs form all units of $\mathrm{X}$ hospital.

The implementation of billing system of inpatient services, each hospital has financial policy related to the application and determination of its financing patterns. In billing system of inpatient, there are several types of fees combined into hospital fee which are facility fee, additional fee, and doctor fee. Facility fee comprises room fee, medical treatment fee, medical procedure services and the use of various medical devices. This fee is a dailywhich occupies hospital treatment bed. The more intensive medical treatment results in the higher cost a patient should pay. The additional cost comprisesradiological examination service fee, laboratory and pharmacy fee.A doctor fee is a service a doctor has already give(11). That hospital fee must be covered by the patient during his medical treatment and every patient must accomplish the payment of all fees according to financing been agreed before. As in hospital $\mathrm{X}$, the determination and the administration of inpatient service fees has been set in hospital regulationthat a hospital director has already made.

Data regarding a report of Quality Assurance Committee of hospital $\mathrm{X}$ in the first semester in the year 2017 mentioned that the speed of inpatient bill information was 3.4 hours (standar $\leq 2 \mathrm{jam}$ ). Measuring the speed of inpatient bill unformation is periodically performed and evaluated by Quality Assurance Committee. Manual cencus is performed by all inpatientbunits, reported every month, recapitulated and data processing is performed by staff of Quality Assurance Committee. In depth Interview with Quality Assurance Committee staf regarding the measurement of the procurement rate of inpatient bill information is :

"It starts when patient is allowed to go home to the bill information given by inpatient nurse to the patient. Provision of inpatient billing information is 
still more than 2 hours since the patient is declared allowed to go home"

Periodically, Quality Assurance Committee makes a report of procurement rate of inpatient bill information to management and the owner of hospital X. Based on the evaluation report of procurement rate of inpatient bill information, it is known that the rate is still longer thanSPM (standard $\leq 2$ hours).

Observation of service flow (workflow) affecting the procurement rate of inpatient bill information is conducted in each related unit such as inpatient unit, laboratory, pharmacy service, inpatient cashier. This observation aims to observe and record all service processes in each unit systematically. The result of observing each unit done by nurses is very complicated. The duty of nursing staff consists of individual nursing activity, collaborative activities between nurses and doctors as well as the patient's administrative related activities. Nursing individual activity comprises making patient's assessment, planning nursing care based on basic need of the patient, monitoring and evaluating patient's conditionand patient care and the documentation related to patient's medical record. Collaborative activities comprise performing medical procedures as advised by DPJP, nutritional intake, educational and information delivery. Some related activities to patient administrative procedures are performing daily reports of service procedures, doing entry of SIRS, providing the information of inpatient billing. Every inpatient medical procedure is manually recorded in double forms as evidence of services and SIRS entry billing is done as well as daily verification by staff of sub unit cashier.

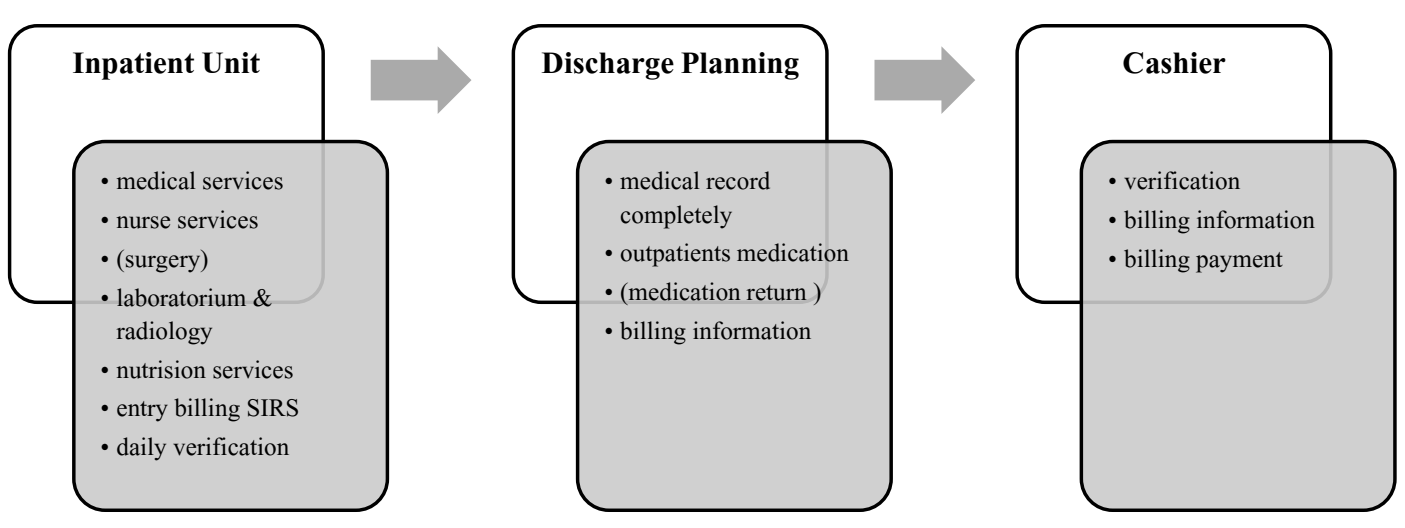

Source: primary data processed, 2017.

\section{Picture 1. Service flow (workflow) of providing inpatient bill information}

Workflow of inpatient bill information is standard service workflow determined by hospital's management. That service procedure aims to gain hospital performance target which has already made. Workflow from one unit to another is a series of activities from the patient's hospitalization to patient's hospital discharge when allowed by DPJP to go home. The distribution of daily responsibilities of staff functions as a guideline in accomplishing their duty. A nurse is strongly demanded to not only complete his roles and duties but he is also able to be an administrator such as performing medical procedure recordings, collecting medical procedure evidence and performing entrybillingof SIRS. Staff of verification is assigned to do daily control activities to ensure that all types of patient's medical procedures have already been documented in SIRS billing and can be proven from manual recording evidence.

Simamora's work (2004) in Jumeri's study argued that performance is gain of certain work that can eventually be reflected directly produced from its quantity and quality(12). The assessment of hospital performance including staff performance is performed by considering its workoutput. Service performance is not merely related to patient's recovery and comfort but it is also from the accuracy and openness of the process of procurement rate of inpatient bill information. Mangkunegara (2007) said that performance is work accomplishment both in quantity and quality aspects that a person can gain depending on the 
responsibility he or she receives ${ }^{12}$. Responsibility and role of each staff in competing his work must be clearly determined and in detailed manners as to gain objective assessment.

On September 27, 2017, the authors conducted an observation by following the daily activities of inpatient billing officer. The billing officer in $\mathrm{X}$ hospital is from cashier sub-unit who has the task of performing daily verification of manual recording, correction, confirmation with other units and cross-checking the SIRS entry billing which has been done by the inpatient staff.

From the observation result of one inpatient unit, it was known that there were 14 patients on that day. It was found that there were 6 incomplete inpatient document files that have not been recorded in the medical treatment evidence form, no evidence of pharmaceutical billing has been attached, and SIRS entry billing has not been conducted. One of the most unrecorded types of action was the administration of oxygen to the patient. The verification activity of the 14 patients was completed within 42 minutes. If there is incompleteness or difference between manual recording and SIRS entry billing, the officer will confirm to inpatient staff, take note on the incompleteness and give feedback on each billing document of each patient.

On the same day, observation on stroke service unit on Hospital X was conducted. Stroke care unit was a one-stop service integration between the high care unit, inpatient room and post-stroke medical rehabilitation service. Stroke unit is one of the units having the most types of medical treatment. There were 4 patients treated in Stroke unit: 3 patients were regular patients and 1 new patient. The billing officer checked the manual record and SIRS entry billing of each patient which was completed within 17 minutes. All verified billing files were declared complete. This is certainly a different finding with other inpatient care units where there are still many recording inaccuracies as well as staff compliance in SIRS entry billing.

Employee performance greatly determines the hospital performance. The performance of each individual will affect the performance of the unit and it will ultimately affect the quality and quantity of hospital performance. According to a research conducted by Indriyatmoko, there were many determinants of the performance of an employee in a company such as leadership style, work motivation, work discipline, but the most influential is the employee's work motivation ${ }^{13}$. Winardi (2005) in the same research explained that motivation is a potential power that exists within a person, can be developed by oneself or developed by outside forces. Motivation may be related to monetary and non monetary reward that may affect performance positively or negatively ${ }^{13}$. From the result of observation and interviews, noncompliance and disobedience of staff related to recording and SIRS entry billing activities are still found. The occurrence of unrecorded types of actions in manual records and SIRS is due to the fact that the nurse feels that this is not his main task, feels that his duties and responsibilities are overwhelming. Some units are not disciplined in performing record-keeping activities but such disobedience has never been given a penalty.

"In dahlia room, cempaka room, and operating rooms sometimes the staff do not input the medical treatment in SIRS billing or not recorded them in medical treatment form". The most common discrepancy is the difference in medical treatment evidence and input in billing, e.g. nurseldoctor performed wound debridement action but the staff inputted minor injuries care which charges differently."

"Nursing compliance by nurses has not been awarded and the punishment"

Incompleteness of the recording of the action caused by the number of double job and the absence of reward and punishment for the nurse is regulated in the hospital regulation. The existence of hospital regulations that regulate the duties and authority and responsibilities of staff detail will be able to create a better working situation.

Motivation is a driving force capable of raising one's passion to work together, work effectively and in integration to achieve the specified level of performance. Jumeri research mentioned that performance can be not optimal due to lack of awareness of the staff to improve competencies that support their tasks, unconformity between job and staff's skills and expertise, lack of staff responsibilities to improve skills and expertise, and a lack of awareness to improve the ability to effectively utilize working hours $^{12}$.

From the result of interview with the head of the inpatient unit regarding the discipline in recording any medical treatment and entry billing in the inpatient unit, it is found that the administrative tasks are often performed at the end of the patient's care activities. Staff often records 
and performs entry billing before shift change or when there is no other activity.

"Treatment is not yet recorded because inpatient nurses forget to record the kind of treatment given or have not performed SIRS entry billing as they have many other activities or undisciplined staff in the record"

According to Fred Luthans (2005), discipline is a force that develops within the worker himself and can cause the worker to voluntarily adjust to the rules that apply in a complex system(13). Although discipline is an internal factor from the worker himself, it can be initiated by external factors. From the search of some care units, employee performance output that does not correspond to organizational goals can still be found. Manual recording activities done by nursing staff or negligence in recording may make some treatments go unrecorded, and this may ultimately lead to potential loss of income for the hospital. Unrecorded part of the action due to the nurse's work in addition to providing the patient's care also perform administrative activities that is manually recording the type of action and tariff and input in SIRS. The risk of losing hospital income can be minimized by the formulation of policies that regulate the implementation of duties and responsibilities of each staff.

According to The Great Dictionary of the Indonesian Language (KBBI), policy is a set of concepts and principles that serves as an outline and basic plan in carrying out a job, leadership and ways of acting. A policy can be derived into a guideline or a standard operational procedure (SOP) as a reference for all staff in completing a job. The availability of facilities and human resources related to the completion of inpatient billing information at Hospital X requires a standard procedure to ensure that the work targets can be completed as expected and planned.

Tiara in her research stated that the implementation of hospital administration information system using billing system can make the work be completed faster, minimize errors and help complete the work on time(14). According to Sutabri (2004), computer has a big impact compared to manual method in storing and running transactions directly in accordance with each unit, can be shared and printed, can speed up repetitive data processing tasks and can be used as a means of employee education and training(14). Hospital $\mathrm{X}$ utilizes manual recording and computerization of inpatient billing information which have been implemented in all units, but the timing of providing inpatient billing information has not been conformed to the standard of $\leq 2$ hours.

The result of fishbone diagram analysis and 5 why state the factors causing the timing of providing inpatient billing information not in accordance with the standard of $\leq$ 2 hours. The factor of people includes no staff in charge (nurse double job), varied skills of human resources, and poor human resource compliance. The factor of procedure includes undetailed coordination policy. The factor of process involves incomplete billing data, inefficient pharmaceutical services, and the factor of policy making involves bad financing policy and no SOP for coordination between units. Through Focus group discussion (FGD), deepening the understanding of each causal factor is done by using the method of 5 why. FGD involves directors and some officials of Hospital X who have the authority in decision making. As the FGD process takes place, sometimes the question of 5 why stops at the second or third question because the root of the problem has been inferred. From the result of FGD, it is known that the root of the problem is the regulation (policy and SOP) on inpatient administration has not been detailed, training on SIRS billing has not been done routinely, and reward and punishment system has not been created.

Based on the root of the problem above, the next stage is developing an alternative solution to improve the speed of inpatient billing information. An alternative solution is considering the availability of current resources capability, accessibility, readiness, and leverage. $\mathrm{C}=$ capability (availability of resources such as funds, facilities and equipment); $\mathrm{A}=$ accessibility (ease, existing problem can be overcome easily or not, ease can be based on the availability of method/ways/technology as well as supporting means such as regulation); $\mathrm{R}=$ readiness (readiness of the executive and readiness of the target such as skill or motivational ability); and $\mathrm{L}=$ leverage (how big is the influence of each criterion on the others in problem solving)(15). The prioritization of solution is done with the board of directors and it is agreed that the preparation of SOPs on more detailed inpatient administration becomes a priority because it has the highest total score in the screening with the CARL method.

Hospital X already has a policy and SOP on giving information of inpatient billing. The aforementioned policy of Hospital X is the director's regulation no.13 of 2016 on Financial Regulation of Hospital X. This policy is stated in the policy of cashier sub-unit.The aforementioned SOP is 
SOP no.06/KEU/X/2016 on the acceptance of inpatient payments for public patient.SOP has set the activities of the staff of each unit, but the types of activities have not been put into detail andthe coordinator in charge ofevery daily activity related to treatment recording procedures and SIRS entry billing has not been appointed.

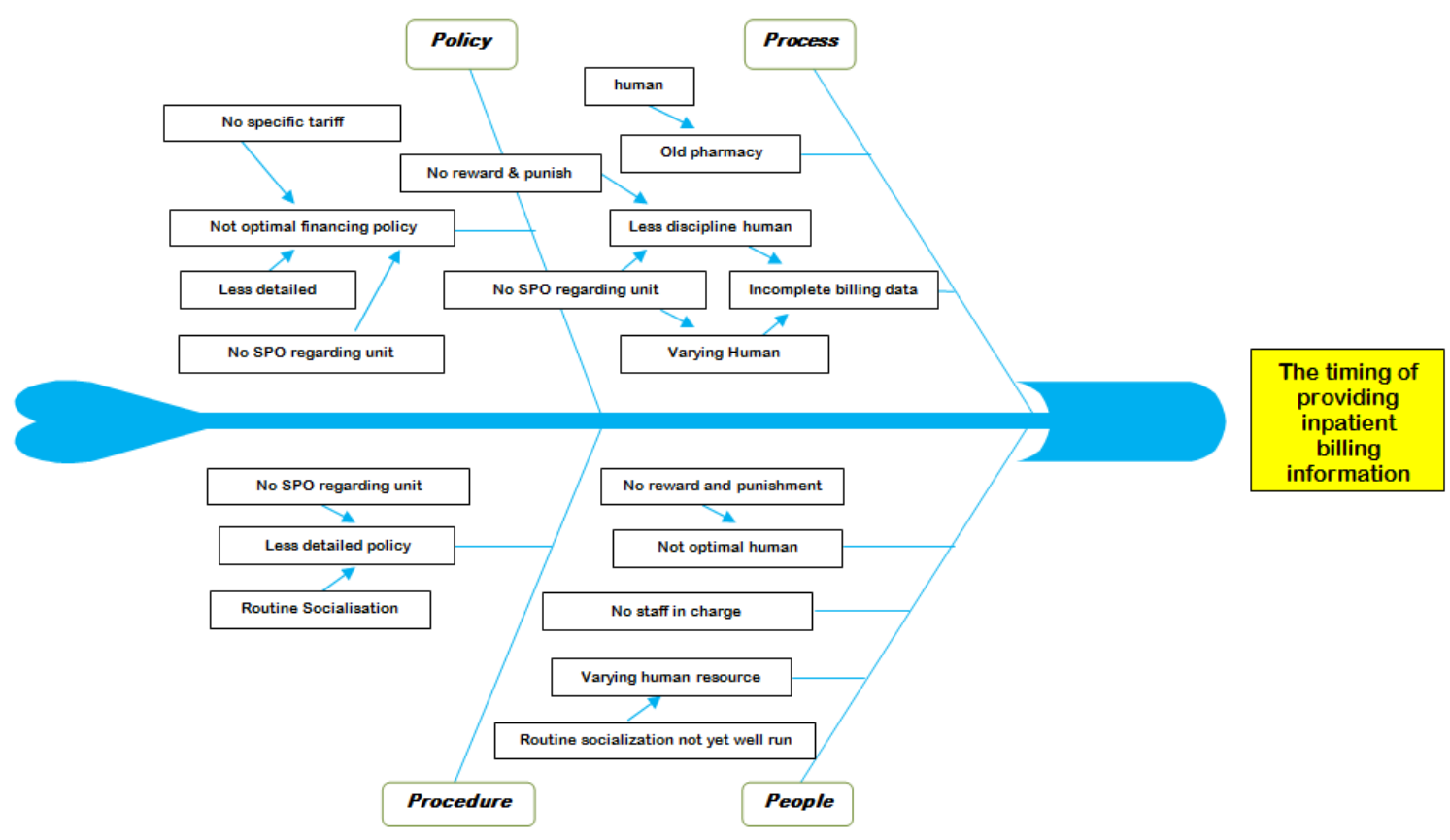

Figure 2. Fishbone Diagram

Table 1. Selection of alternative solutions with CARL method

\begin{tabular}{lllllcc}
\hline \multicolumn{1}{c}{ Alternatif Solusi } & C & A & R & L & Jumlah & Ranking \\
\hline SOP on detailed inpatient administration & 9 & 8 & 8 & 8 & 4608 & I \\
Routine training on SIRS billing & 8 & 8 & 8 & 8 & 4096 & II \\
Reward-punishment system & 8 & 6 & 7 & 7 & 2352 & III \\
\hline
\end{tabular}

Source: primary processed data, 2017.

According to Van Meter and Van Horn in Triana's research(2015), the implementation of policy refers to how the policy is carried out. The implementation of policy is formulated as an action carried out by individuals, officials, and groups geared towards the achievement of the goals that have been set in the policy decisions(16). The implementation of the policy by the entire staff will determine the achievement of the goals of inpatient billing information.

Sources that can support the implementation of policy include staff, information, authority, and facilities(16). Policy governing the duties and authority of each staff in using resources of Hospital $\mathrm{X}$ will be able to direct the achievement of organizational goals. According to Robbins
(1996) in Jamaluddin's research, organizational culture is an organizational identity. Organizational culture significantly influences employee commitment(17). Incomplete recording may be caused by poor commitment and poor staff compliance, carelessness and staff who have not been trained to use SIRS billing. Ironically, this can turn into a negative organizational culture if no controlling measures are taken by the management of hospital X.

A detailed SOP on inpatient administration may affect staff's compliance and obedience in conducting inpatient billing administration. Staff who does not keep records in medical treatment form and SIRS entry billingcan prolong the process of inpatient billing 
settlement because re-verification should be done more thoroughly and this takes longer time.

Jamilatus, in her research conducted in Muhammmadiyah University Hospital Malang, stated that the implementation of financial SOP did not statistically increase the timing of providing inpatients billing information significantly. The implementation of financial SOP can improve the waiting time of information transfer although it is still not in accordance with the standards of $\leq$ 2 hours (7). No matter how small the impact of the implementation of financial SOP to the increased speed of inpatient billing information, it is able to improve patient's waiting time in hospital administration process.

According to the review of lean, waiting time of inpatient billing information which has not conformed to the standard is a wastethat must be eliminated. Al- Araidah and Momani mentioned that the method of lean hospitalcan work well if the process flows smoothly. Therefore, things that impede the flow of process must be eliminated because they are a waste that can interfere with service. Concepts to reduce waste and to make improvement is define, measure, mapping, eliminate waste, improve and control (DMAIC)(9). Defining the root of the problem, measuring, observing service flow and eliminating waste are important steps in the efforts to improve the quality of hospital administrative services. Implementing solution priorities and carrying out monitoring and control will direct quality improvement efforts which occur continuously in accordance with the cycle until they reach their original destination. According to Gasperz (2007) in Fijar's research, leanis a continuous effort to eliminate waste and increase the value added of products(goods or services) in order to provide value to the customer(customer value)(9). Every effort to increase the timing of providing inpatient billing information will add value to products or services that will increase customer satisfaction to the service of hospital X.

A study in Regional Health Bureau hospital in the eastern part of Ethiopia shows that satisfaction level decreases with increasing length of waiting time(18). Patient experience in waiting for service can affect his/her perception of the quality of service and can further determine customer action on his/her future purchases. Patients who come to a hospital for treatment want to get the service they need immediately without having to wait for a long time(5). Some indicators of customer satisfaction ratings to hospital services still indicate that the main causes of patient dissatisfaction is related to medical services of the hospital. In his study, David stated that the highest dissatisfaction ( $>50 \%$ ) of patients in the hospital is the aspect of doctor delay and an apology from the doctors when they are late(19). However, hospital administration services remain a very important indicator in assessing the quality of hospital services.

The workflow analysis is used to measure waiting time in delivering inpatient billing information by calculating the service provided by hospital staff. Fourdimension approach, i.e. objective(actual waiting time), subjective or perceptions(perceived waiting time), cognitive(evaluation of the process of waiting), and affective(response to the process of waiting) can be done(5). Actual waiting time isassociated with the workflow that can be measured objectively by evaluating each point of service units that affects the waiting time of inpatient billing information. Actual waiting timeassessment is very important because it illustrates how effective and efficient an internal process of institutional business services. Directness and simplicity of a business process can support the achievement of the speed of service delivery. On the other hand,perceived waiting timeis a feeling or perception when a customer waits for a service. If assessed, perceived waiting timewill be biased with actual waiting time assomeone will think that he waits longer than he does in fact(20). Therefore, a detailed and uniform process of service flow identification will be used as the basis for recommended action and action plan priority which are more objective(21).

Uniform service flow can be used as a guide to the preparation of detailed daily activities of each staff unit of the different services. The scope of the service units and the types of task details must be set in SOP coordinated between units in the settlement of inpatient billing information that is currently not in accordance with the standards of $\leq 2$ hours. The absence of a responsible officer (nurse double job) becomes the problem of providing billing information beyond the specified standard. The duties and responsibilities of the nurses are not only in providing the patient's care but also the administrative task of manually recording the actions and inputs in the SIRS. Revised policies and SOP on inpatients administration in hospital $\mathrm{X}$ is expected to be a more detailed and clear work reference for each unit, and also for every staff in order to reach the standard speed in the delivery of inpatients billing information. 


\section{CONCLUSION}

The absence of a responsible officer (nurse double job) becomes the problem of providing billing information standard of $\leq 2$ hours. The duties and responsibilities of the nurses are not only in providing the patient's care but also the administrative task of manually recording the actions and inputs in the SIRS. Revised policies and SOP on inpatients administration in hospital $\mathrm{X}$ is expected to be a more detailed and clear work reference for each unit, and also for every staff in order to reach the standard speed in the delivery of inpatients billing information. Compliance and obedience of the staff in carrying out inpatient billing administration activities in accordance with the SOP will be able to increase the speed of information transfer related to inpatient billing and improve the brand image of the hospital. Further research on the implementation of the new policy and SOP toward the improvement of the speed of inpatient billing information and patient satisfaction related to the process of hospital administration is required, and thus pre and post implementation in Hospital X can be evaluated. The preparation of new policy and SOP is expected to be a leverage solution that is significant to the increase of the timing of providing inpatient billing information.

\section{REFERENCES}

1. Depkes. Kepmenkes No 129 tentang Standar Pelayanan Minimal, . 2008.

2. Jihan Anfa DC. Evaluasi Kinerja Billing System Rawat Inap Menggunakan Kerangka PIECE. Jurnal Administrasi Kesehatan Indonesia. 2016; Vol. 4 No. 1:18-27.

3. Adarini LS, Syah TYR. Service blueprint manajemen pasien pulang (discharge) pada pelayanan rawat inap. Jurnal Online Internasional \& Nasional Universitas 17 Agustus 1945 Jakarta. 2016;3(2):60-73.

4. Ried LD, Wang F, Young H, Awiphan R. Patients' satisfaction and their perception of the pharmacist. JAPHA-WASHINGTON-. 1999;39:835-42.

5. Antonides G, Verhoef PC, Van Aalst M. Consumer perception and evaluation of waiting time: A field experiment. Journal of Consumer Psychology. 2002;12(3):193-202.

6. Susanti NLPD, Wulandari IA. Gambaran tingkat kepuasan pasien rawat inap kelas ii terhadap pelayanan keperawatan di RSUD Sanjiwani Gianyar tahun 2015. Jurnal Riset Kesehatan Nasional. 2017;1(1):34-40.

7. Anwar JS. Study on directors policy on discharge waiting time of inpatients in University of Muhammdiyah Malang Hospital. Journal of Applied Management (JAM). 2017; Vol. 15. N0. 2:252-60.

8. Bachri B. Menyakinkan validitas data melalui triangulasi pada penelitian kualitatif. Jurnal Teknologi Pendidikan. 2010; Vol 10 (1):46-63.

9. Fijar Alpasa LF. Penerapan Konsep Lean Service dan DMAIC untuk Mengurangi Waktu Tunggu Pelayanan. Jurnal Online Institut Teknologi Nasional. 2014; Vol 02 No. 03:108-17.

10. Evy Hariana GYS, Annisa Risty Rahmanti. Penggunaan Sistem Informasi Manajemen Rumah Sakit (SIMRS) di DIY. Sesindo. 2013.

11. Hoga Saragih LL, Bobby Reza, Didik Setiyadi. Analysis Information System of Inpatient Billing Systems Support for Consumables Logistics using PIECES Framework: Case Study Promedika Hospital. Journal of Information Systems. 2012; Vol. 8(1):16-21.

12. Jumeri Dahri P, Adam Idris. Kinerja Aparatur pada era Pelaksanaan Pelayanan Administrasi Terpadu Kecamatan (Paten) di Kantor Camat Sangasanga Kabupaten Kutai Kartanegara. Jurnal Administrative Reform. 2014;Vol. 2 no. 3:433-44.

13. Indriyatmoko AW, Lamidi. Pengaruh Gaya Kepemimpinan, Motivai Kerja dan Disiplin Kerja terhadap Kinerja Pegawai Kantor Pos Boyolali. Jurnal Manajemen Sumber Daya Manusia. 2016; Vol.10 No. 1:76-86.

14. Tiara Kharaini HS, Riyadi. Implementasi Sistem informasi Administrasi Rumah Sakit Berbasis Komputer untuk Meningkatkan Kinerja Karyawan (Studi pada Billing System RSUD Dr. Syaiful Anwar Malang). Jurnal Adminitrasi Bisnis (JAB) 2013; Vol. 6 No. 2 1-9.

15. Indra Wahyu H NIF, Hartojo. Pengembangan Jenjang Karir sebagai Strategi Mengelola Ketidakpuasan Kerja Perawat di Rumah Sakit. Jurnal Kedokteran Brawijaya. 2016;Vol 29 no. 3:285-90.

16. Rahayu TP. Implementasi Kebijakan e-procurement unutk mewujudkan efisiensi dan transparansi (studi pada PT PLN Persero area Malang). Jurnal Admnistrasi Publik (JAP). 2015;Vol. 1 No. 2:290-8.

17. Jamaludin Kabalmay AVH, Sukiswo Dirdjosuparto. Pengaruh Budaya Organisasi terhadap Komitmen 
Pegawai Politeknik Perikanan Negeri Tual. Juima. 2015; Vol. 5 No. 1:34-42.

18. Abdosh B. The quality of hospital services in eastern Ethiopia: Patient's perspective. The Ethiopian Journal of Health Development (EJHD). 2016;20(3).

19. David TH, Erika Widayanti L. Hubungan Keterlambatan Kedatangan Dokter terhadap Kepuasan Pasien di Instalasi Rawat Jalan. Jurnal Kedokteran Brawijaya. 2014;Vo. 28 No. 1:31-5.

20. Jones P PE. Managing perceptions of waiting times in service queues. International Journal of Service Industry Management. 1996;7(5):47-61.

21. Nancy M, Pramuji Eko Wardani Pendekatan lean hospital untuk perbaikan berkelanjutan (continuous improvement) proses pelayanan instalasi farmasi Jurnal Manajemen dan Pelayanan Farmasi. 2014; Vol. 4 Nomor 2:91. 